\title{
NUTRIENT CONTENTS OF SOYABEANS: A GUIDE FOR SUGARCANE GROWERS UNDER FAST TRACK LAND REFORM PROGRAMME [FTLRP] IN ZIMBABWE
}

Shoko $\mathrm{MD}^{1^{*}}$ and Zhou $\mathrm{M}^{2}$

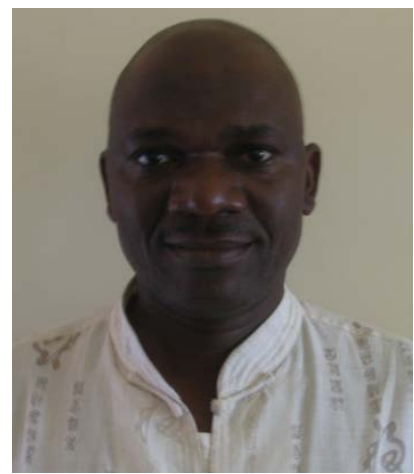

Munashe Shoko

*Corresponding author Email: munashoko@yahoo.co.uk

${ }^{1}$ Faculty of Agricultural Sciences, Great Zimbabwe University, Box 1235, Masvingo, Zimbabwe

${ }^{2}$ South African Sugarcane Research Institute, Private Bag X02, Mount Edgecombe, KwaZulu-Natal 4300, South Africa 


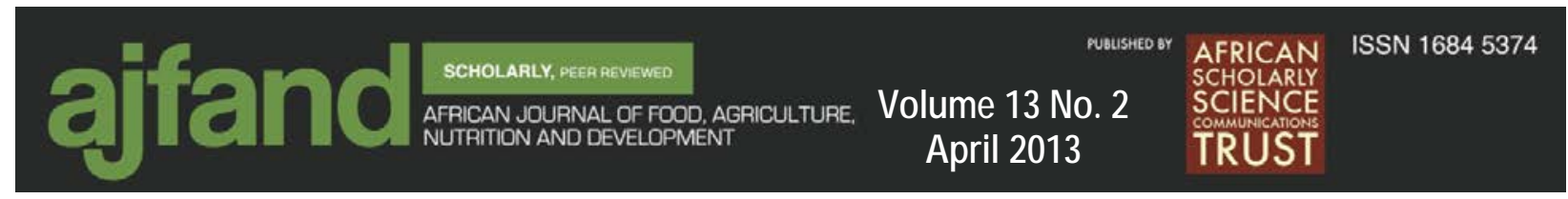

\begin{abstract}
Soyabean biomass, stover and roots when incorporated into the soil can improve the organic matter and the carbon $(\mathrm{C})$ : nitrogen $(\mathrm{N})$ ratio of the soil. Of its total $\mathrm{N}, 60$ $90 \%$ is translocated into the seed. This research was conducted on sandy clay loams of the lithosol group under the Zimbabwe soil classification system at The Zimbabwe Sugar Association Experiment Station (Z.S.A.E.S) in the South Eastern Lowveld, the leading sugarcane producing region in Zimbabwe. The objectives of this research were to: 1) analyse the nutrient content of the soyabeans under study, 2) assess the contributions of the various soyabean parts to soil fertility, 3) determine the liming potential of the soyabeans and 4) determine the forage potential of the two soyabean varieties as livestock feeds. The following parameters were measured: 1) nutrient composition of the vegetable and grain soyabeans, soyabean biomass 2 ) nitrogen fixed by both grain and vegetable soyabeans. Vegetable soyabeans (variety S114) and grain soyabeans (variety Storm) were used for this study. Vegetable soyabeans had higher nitrogen, phosphorus and potassium while grain soyabeans had higher calcium and magnesium. This shows that vegetable soyabeans as a nitrogen fixing crop have Plural? the potential to ameliorate soil fertility. However, grain soyabeans seem to have better liming potential than vegetable soyabeans. Forage Storm can improve the magnesium and calcium constituency of livestock while vegetable soyabeans can influence the phosphorus content. The two elements are critical to lactating cows and young stock. The crops have high levels of calcium and magnesium, which are the critical elements for the improvement of soil $\mathrm{pH}$. Interestingly, high nitrogen $(\mathrm{N})$, phosphorus $(\mathrm{P})$ and potassium $(\mathrm{K})$ contents were observed in grain soyabeans. These nutrients in grains are not returned to the soil as the grains are sold as a commercial crop. The economic benefits of growing soyabeans accrue from the nutrients that remain in the leaves, petioles, stems and shells that are ploughed into the soil during land preparation.
\end{abstract}

Key words: soil fertility, soyabeans, smallholder farmer 


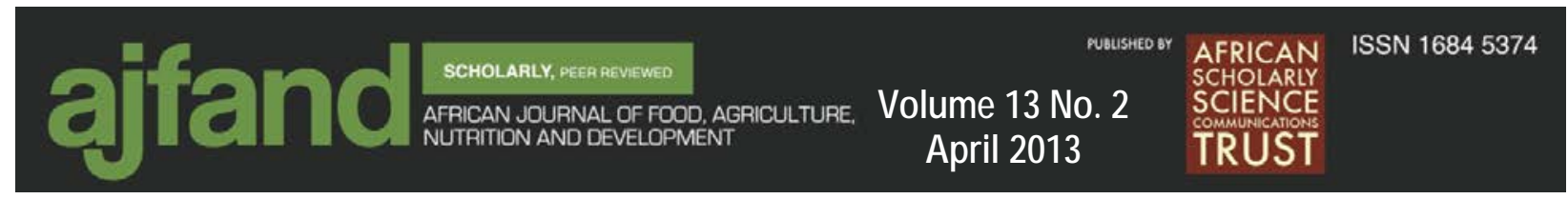

\section{INTRODUCTION}

In the year 2000, the Government of Zimbabwe embarked on a Fast Track Land Reform Programme [FTLRP]. This programme saw over 800 new farmers allocated pieces of land for sugarcane production in the South Eastern Lowveld of Zimbabwe [1]. The newly resettled farmers have diversified into livestock production to supplement their low income from sugar sales [2].

The newly resettled farmers practice monoculture sugarcane production with few plough-outs [3]. The monoculture approach is common among sugarcane growers and results in a decline in yields, depleted soil fertility, lowering of soil organic matter $(\mathrm{OM})$, deterioration in physical soil conditions and build-up of pests and diseases [3]. Findings from Papua Guinea, Fiji, South Africa and Philippines indicated that a yield of $100 \mathrm{t}$ cane / ha depleted 20kg N/ kg, $133 \mathrm{~kg} \mathrm{P} / \mathrm{ha}, 125 \mathrm{~kg} \mathrm{~K} / \mathrm{ha}$ and $10 \mathrm{~g} \mathrm{OM} / \mathrm{kg}$ from the soil [4]. Monoculture practices in sugarcane increases soil acidity by overmining the basic cations. There is need for newly resettled sugarcane farmers in Zimbabwe to practice sustainable rotations so as to reduce serious viability problems because of high costs and unavailability of fertilizers on the market [5].

Soyabean biomass, stover and roots when incorporated into the soil can improve organic matter and the $\mathrm{C}$ : $\mathrm{N}$ ratio of the soil $[6,7]$. Of its total $\mathrm{N}$ in the soyabean plant, $60-90 \%$ is translocated into the seed [8]. Soyabeans can be used as forage crop for livestock.

Soyabeans can be used as a forage crop for livestock to provide important minerals like $\mathrm{Ca}, \mathrm{P}, \mathrm{K}$ and $\mathrm{Mg}$ [9]. Ca and P play roles as components in bones, teeth and other metabolic functions. The optimum Ca: $\mathrm{P}$ is $2: 1$ [10]. Mg is an important element in the prevention of magnesium tetany condition in livestock. The newly resettled farmers are now diversifying into livestock production as well. Livestock require the following critical levels of minerals (\%); Ca (0.90), Mg (0.10), K (0.60) and P (0.60) [11].

This research will go a long way in helping farmers who practice mixed farming to tape benefits accrued from the legume crop for both their sugarcane fields and livestock. The objectives of the study were to (i) analyse the nutritive value of the various parts of the vegetable and grain soyabean plants; (ii) assess the potential contributions of the soybean parts to soil fertility; (iii) determine the liming potential of the soyabean crop; and (iv) determine the forage potential of soybeans as livestock feeds.

\section{METHODOLOGY}

Experimental site: This study was carried out at the Zimbabwe Sugar Association Experiment Station (ZSAES) in the South Eastern Lowveld of Zimbabwe, $430 \mathrm{~m}$ altitude $21^{\circ} 01^{\prime} \mathrm{S}$ latitude and $28^{0} 38^{\prime} \mathrm{E}$ longitude. This experiment was conducted from 2005 to 2010 under furrow irrigation. In the top 0 to $30 \mathrm{~cm}$, the soil is sandy clay 


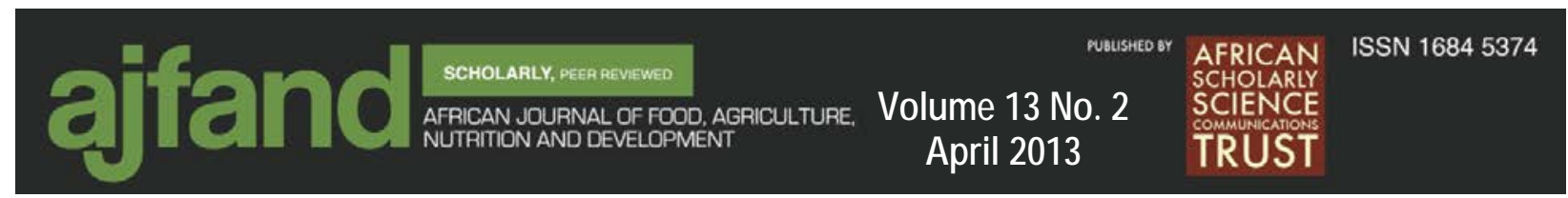

loam and is brown in colour. The average annual rainfall is $625 \mathrm{~mm}$ per annum, falling predominantly in the hot summer months of October to March. Mean air temperatures vary from about $26^{\circ} \mathrm{C}$ in summer to $16^{\circ} \mathrm{C}$ in winter.

Experimental design and treatments: Treatments used were vegetable soyabeans (variety, S114) and grain soyabeans (variety, Storm) with four replicates. The field was demarcated into 32 plots of $230 \mathrm{~m}^{2}$ arranged in a Randomized Complete Block Design (RCBD).

Soyabean production phase: Soyabeans were planted during the 2003/2004 and 2004/2005 seasons. Row marking was done at an inter- row spacing of $0.75 \mathrm{~m}$, intrarow of $0.05 \mathrm{~m}$ and a depth of $0.05 \mathrm{~m}$. Phosphorus was applied as basal application to the furrow at $100 \mathrm{~kg} \mathrm{Pha}^{-1}$ using single super phosphate. Vegetable soyabean (cv. S114) and grain soyabean (cv.Storm) were planted for this study. These varieties were chosen because they do well in this agro-ecological zone 5 (low rainfall region) of Zimbabwe.

Crop Management: Disease inspection was done once every month. Herbicides, Commando and Lasso were used for controlling weeds in soybean plots at planting. Irrigation was scheduled using evaporation data from a US Weather Bureau Class A pan. Water was applied at 50\% depletion of total available water (TAM) to a depth of $1 \mathrm{~m}$.

Soyabean biomass determination and nutrient analysis: Five samples were taken from a net plot of $5 \mathrm{~m}^{2}$ in each plot. All plants in the net plots were cut at ground level for the determination of total biomass. The samples were weighed and then oven dried at $70^{\circ} \mathrm{C}$ to a constant weight. Vegetable soyabeans were harvested whilst green and then ploughed under. Soyabean grains were harvested when it was mature and the whole crop was removed from the field and only the underground biomass was ploughed under.

From the sampled five plants per net plot, 20 leaves, 5 pods, 10 petioles and 1 stem and 50 grains were analysed. The samples were wet digested and then analysed for nitrogen using the micro-kjeldahl method, phosphate using sodium molybdate and bases using $2.5 \%$ EDTA method.

Estimation of $\mathbf{N}_{\mathbf{2}}$ fixation: The proportion of nitrogen fixed was estimated using $\mathrm{N}$ difference method. Weeds from the unfertilized plots were used as a non-fixing reference crop. The weeds were also sampled along with the soyabean plants. Both the soyabean and weed samples were oven-dried to constant weight at $60^{\circ} \mathrm{C}$ and then nitrogen was determined (maturity stage) using the Micro- Kjeldahl method. The $\mathrm{N}_{2}$ fixation was determined at maturity of the soyabeans. Nitrogen fixation in grain soyabeans was determined at 120 days after planting (maturity stage) and in vegetable soyabeans at 80 days after planting (maturity stage). 


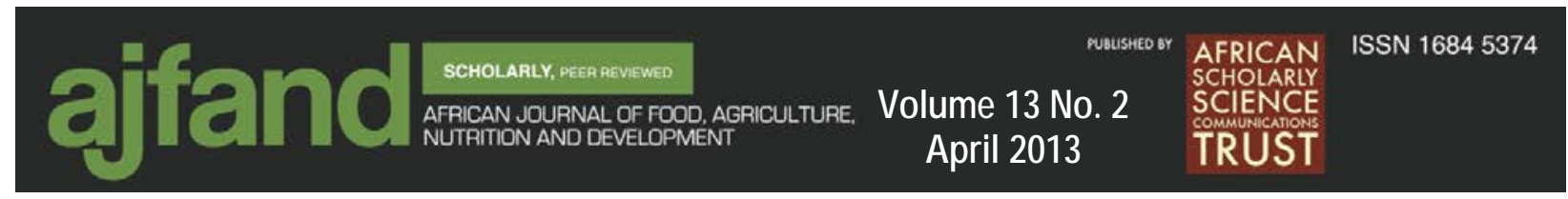

Statistical analyses: The plant and soil nutrient data were analysed by standard (ANOVA) using MSTAT version 4. The data were inferred using $\mathrm{P}<0.05$.

\section{RESULTS}

\section{Soyabean biomass and estimate of $\mathbf{N}_{\mathbf{2}}$ fixed:}

Vegetable soyabeans had higher biomass and fixed more $\mathrm{N}$ than grain soybeans (Table 1)

Total nutrients per plant: There were significant differences $(P<0.05)$ for nitrogen, phosphorus, potassium and calcium but not for magnesium between grain and vegetable soyabean (Table 2). Vegetable soyabeans had 18\% N, 23\% P, $11 \% \mathrm{~K}, 21 \%$ $\mathrm{Ca}$ and $4 \% \mathrm{Mg}$ more than grain soyabeans at 81 days after planting.

Nutrients in plant parts: Percent nutrient status of leaves, petioles, pods and stems of vegetable and grain soyabeans at 81 days after planting are shown in Table 3 and Figure 1. In both grain and vegetable soyabeans, N, P and K were highest in pods and lowest in petioles. However, leaves and petioles had the highest Ca. Mg was highest in petioles as well.

Leaves: Nitrogen content in the leaves of both vegetable and grain soyabeans were not significantly different. There were significant differences $(P<0,05)$ for phosphorus, calcium and magnesium. Grain soyabeans had 3\%, 10\%, $39 \%$ and $8 \%$ more P, K, Ca Mg, respectively, than vegetable soyabeans (Tables 3 and 4).

Petioles: Vegetable soyabean had significantly $(\mathrm{P}<0.05)$ more nitrogen, more potassium, less calcium and less magnesium than grain soyabean. Vegetable soyabean had $60 \%, 13 \%$, and $32 \%$ more $\mathrm{N}, \mathrm{P}, \mathrm{K}$ than grain soyabean. However, grain soyabeans had $42 \%$ and $31 \%$ more calcium and magnesium respectively than vegetable soyabean (Tables 3 and 4).

Pods: There were no significant differences between the nitrogen, phosphorus, potassium and magnesium in the pods of grain and vegetable soyabeans. Vegetable soyabean had significantly $(17 \%)$ more calcium $(\mathrm{P}<0,05)$ than grain soyabean.

Stems: Vegetable soybean had significantly $(\mathrm{P}<0.05)$ more nitrogen, potassium, calcium and magnesium than grain soyabean.

\section{Nutrients in different parts of grain soyabeans}

The results of the analysed mature grain soyabeans harvested after 120 days are shown in Figure 1. Percent $\mathrm{N}$ and $\mathrm{P}$ were highest in the seed (grain) and lowest in pods (shells). The seed has a high harvest index. Potassium (\%) was highest in pods (shells) whereas leaves and petioles contained the highest \% of Ca. Mg was highest in petioles and lowest in grain. 

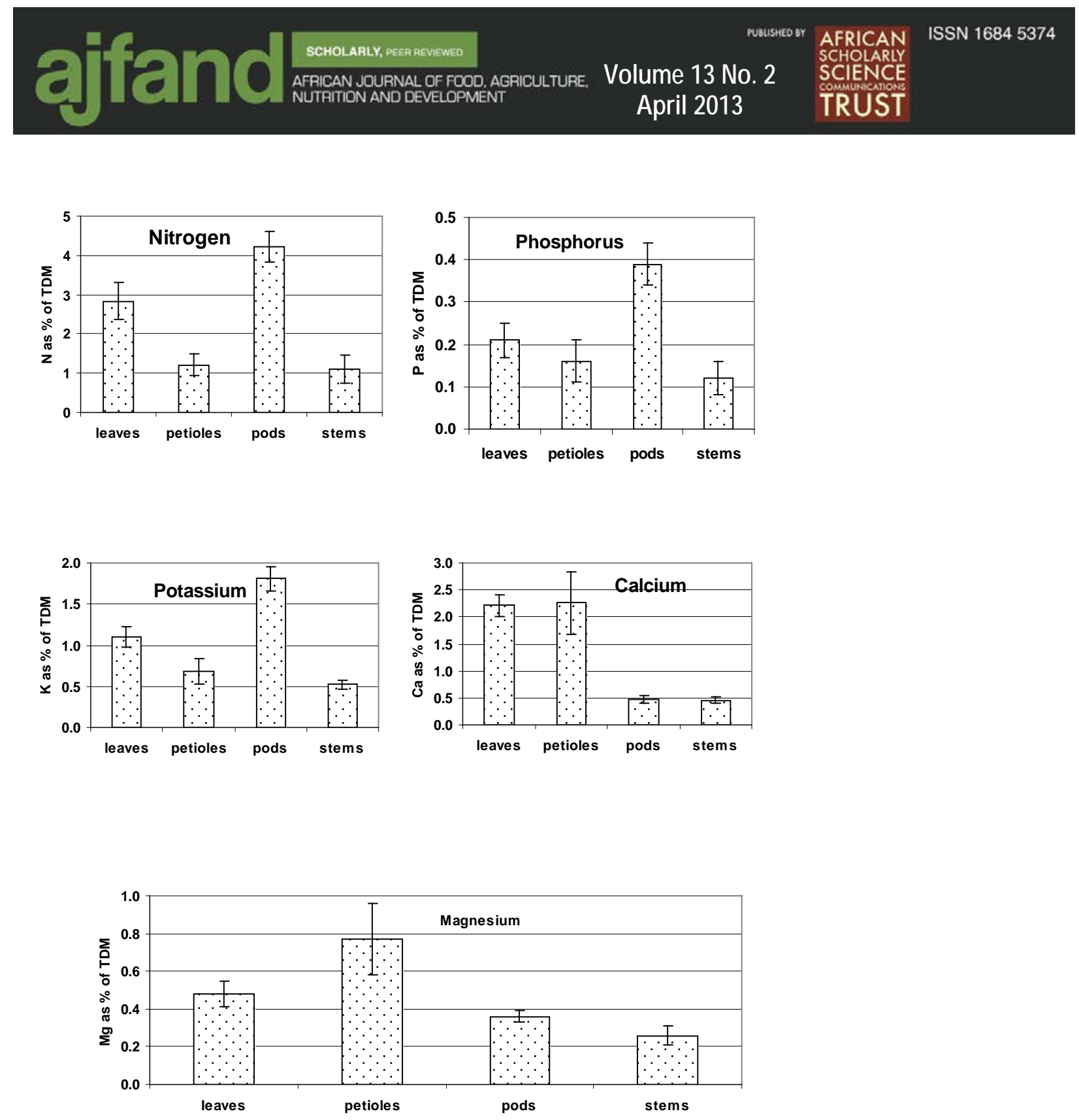

Figure 1: Nitrogen, phosphorus, potassium, calcium and magnesium status in leaves, petioles, pods and stems of grain soya sampled at 81 days after planting

\section{DISCUSSION}

Soil fertility improvement: The incorporation of vegetable soyabean parts such as leaves, stems and petioles at green stage will help to increase $\mathrm{K}, \mathrm{Ca}$ and $\mathrm{Mg}$ in the soil. These basic cations are essential for correcting soil acidity, which is important for sugarcane growth and development. $\mathrm{Mg}$ will help in the photosynthesis process. This can increase the productivity of cane. Calcium will boost cell division and increase cane and sugar yields. This is in line with the findings of ( 11. 


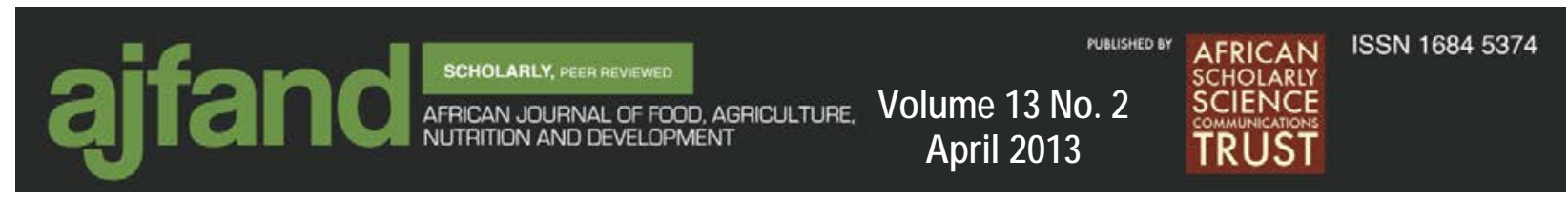

Liming potential: $\mathrm{Ca}$ and $\mathrm{Mg}$ are essential liming components to neutralize the hydrogen ions, which are sources of acidity [12]. The incorporation of the whole vegetable soyabean excluding pods at maturity, which is 81 days after planting, can increase soil $\mathrm{pH}$ considering the amount of $\mathrm{Ca}$ and $\mathrm{Mg}$ shown on Table 3.

Nutrient ratio: The $\mathrm{N}$ : $\mathrm{Ca}$ for grain and vegetable soyabean is 1.7 and 5.2, respectively while the $\mathrm{N}$ : $\mathrm{Mg}$ ratio for grain and vegetable soyabean is 2.4 and 8.5, respectively. These ratios show that the soyabean if let to mature (grain) and pods taken out will fix fairly low N. Pods have a high harvest index consistent with prior findings (9).

However, harvesting green pods (vegetable) can help the farmers to incorporate most $\mathrm{N}$ into the soil. The $\mathrm{Ca}$ and $\mathrm{Mg}$ levels will improve soil fertility and the $2.8 \mathrm{Ca}$ : $\mathrm{Mg}$ ratio (3.0 recommended) can improve crop growth and development.

The Ca: $\mathrm{P}$ is 6 , which is above the recommended of 5.1. This, therefore, ensures the availability of the two nutrients to the subsequent crop.

Smallholder sugarcane growers and integrated farming: The small-holder sugarcane farmers who were resettled under the land reform programme are now diversifying into livestock production as well. Soyabean has the potential to be used as forage and thereby supplement some nutritional deficiencies in beef and dairy cattle as well as in goats. The nutrient values excluding pods for the two soyabean varieties show that $\mathrm{P}, \mathrm{Ca}, \mathrm{K}$ and $\mathrm{Mg}$ have values higher than the critical levels (Table 3 and 4). Soyabeans can be useful supplements since they have higher values than recommended ones [11]. If $\mathrm{Mg}$ is lacking in the soil, it leads to a condition called hypomagnemia or magnesium tetany in livestock. Ca and $\mathrm{P}$ are also important in physiological growth of livestock particularly in bone formation [12].

\section{CONCLUSION}

Vegetable soyabeans showed higher nitrogen, phosphorus and potassium but had less calcium and magnesium than grain soyabeans in terms of total plant nutrients. There was more phosphorus, potassium, calcium and magnesium in leaves of grain soyabeans than in vegetable soyabeans. However, more nitrogen was noted in vegetable soyabeans. Overall, the differences between grain and vegetable soyabeans were highly significant. The differences in nutrients between the plant parts of the same variety were also highly significant. Interestingly, higher nitrogen, phosphorus and potassium content was observed in grain soyabeans.

The economic benefits which can be driven from the growing of soyabeans is from the nutrients that remain in the leaves, petioles, stems and shells that are ploughed into thesoil during land preparation.

Vegetable soyabeans had higher N, P, K content and lower Ca and Mg content than grain soyabeans. Soyabeans can be a good source of important minerals like $\mathrm{Ca}, \mathrm{Mg}$, 


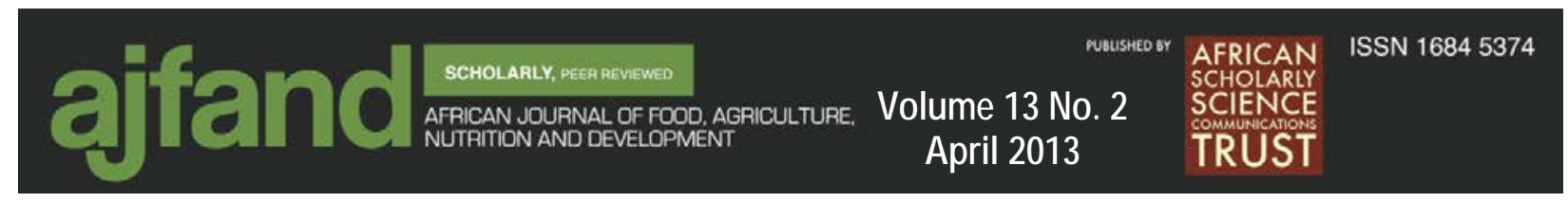

$\mathrm{K}$ and $\mathrm{P}$ for livestock of the small-holder sugarcane farmers. When incorporated into the soil, soyabeans can have some liming effect because they contain acceptable levels of Ca and Mg. 
Table1: Above ground dry biomass at maturity (t / ha), plant population (plants / ha) and $\mathrm{N}$ fixed (kg/ha)

\begin{tabular}{lccr}
\hline Treatment & Plant population & \multicolumn{1}{l}{$\begin{array}{l}\text { Biomass } \\
(\boldsymbol{t} / \mathbf{h} \boldsymbol{h}) \mathbf{k g} / \mathbf{h a})\end{array}$} & N fixed \\
\hline Vegetable soybeans & 142725 & 5.92 & 118 \\
Grain soybean & 156575 & 4.43 & 58 \\
s.e & 1.44 & 1.44 & \\
c.v (\%) & 15.74 & 15.74 & \\
& & &
\end{tabular}

Source: [2]

Table 2: Nutrient composition of the soyabean plant parts

\begin{tabular}{lccccc}
\hline $\begin{array}{l}\text { Treatment } \\
\text { Mg }\end{array}$ & \multicolumn{1}{c}{$\mathbf{N}$} & \multicolumn{2}{c}{$\mathbf{P}$} & $\mathbf{K}$ & Ca \\
\hline Grain & 9.39 & 0.87 & 4.12 & 5.51 & 1.91 \\
Vegetable & 11.10 & 1.07 & 4.56 & 4.57 & 1.83 \\
Sig & $*$ & $*$ & $*$ & $*$ & $\mathrm{~ns}$ \\
c.v $(\%)$ & 8.68 & 14.18 & 8.13 & 9.08 & 13.07
\end{tabular}

Means within the same column are significantly different at $\mathrm{P}<0.05$. ns $=$ not significant 
Table 3: Percentage nutrient in different vegetable soybean plant parts at 81 days after planting

\begin{tabular}{lccccc}
\hline Plant part & $\mathbf{N}$ & $\mathbf{P}$ & $\mathbf{K}$ & $\mathbf{C a}$ & $\mathbf{M g}$ \\
\hline Leaves & 2.88 & 0.18 & 1.00 & 1.82 & 0.40 \\
Petioles & 1.93 & 0.18 & 0.90 & 1.59 & 0.59 \\
Pods & 3.97 & 0.41 & 1.86 & 0.55 & 0.37 \\
Stems & 2.32 & 0.30 & 0.80 & 0.61 & 0.47 \\
\hline
\end{tabular}

Table 4: Percentage nutrient in different grain soyabean plant parts at maturity

\begin{tabular}{|c|c|c|c|c|c|c|}
\hline Plant part & $\mathbf{N}$ & $\mathbf{P}$ & $\mathbf{C a}$ & Mg & & \\
\hline Leaves & 2.84 & 0.21 & 1.10 & \multicolumn{2}{|c|}{2.21} & 0.48 \\
\hline Petioles & 1.21 & 0.16 & 0.68 & 2.26 & 0.77 & \\
\hline Pods & 4.22 & 0.39 & 1.81 & 0.47 & 0.36 & \\
\hline Stems & 1.11 & 0.12 & 0.52 & 0.46 & 0.26 & \\
\hline
\end{tabular}




\section{REFERENCES}

1. Moyo S, Sukume C, Chidawanyika $\mathbf{C}$ and $\mathbf{H}$ Binswanger Agricultural growth and land reform in Zimbabwe: Assessment and recovery options. 2004.

2. Shoko MD, Tagwira $\mathbf{F}$ and $\mathbf{M}$ Zhou The potential of reducing nitrogen fertilizers in a soyabean-sugarcane production system in Zimbabwe. African Journal of Agriculture Research.2007; 2 (9): 16-26.

3. Sundara B Sugar cane Irrigation Handbook. UBS. India.1982.

4. Hartermink A E and AW Wood Sustainable land management in the tropics: The case of sugarcane plantations. University of Technology. Papua New Guinea.1998.

5. Meyer $\mathbf{J} \mathbf{~ W}$ and $\mathbf{V}$ Antwerpen Soil degradation as a factor in yield decline in the South African Sugar Industry. International Society of Sugarcane Technologists Proceedings XX1V Congress 21, September. 2001.

6. Anonymous. Zimbabwe Sugar Association Experiment Station Research Report 1998- 2000. Chiredzi, Zimbabwe. 2000.

7. Zhou M Preference of varieties N14 and Nco376 in the south eastern lowveld of Zimbabwe.2004. Proc S Afr Sug Technol Ass 78: 137-147.

8. Garside AL and JE Berthelsen Management of legume biomass to maximize benefits to the following sugarcane crop. 2004 Proc. Aust. Soc. Sugarcane Technol.26.

9. Giller KE, McDonagh JF and G Cadish Can biological nitrogen fixation sustain agriculture in the tropics? CABI Publishing. Wallingford.1994.

10. Sullivan $\mathbf{P}$ Overview of cover crops and green manures. 2003.Am. Soc. Sugarcane Technol 20: 67-72.

11. Anonymous Nutrient requirements for beef cattle. University of Florida-IFAS extension. 2007.

12. Tisdale S L, Havlin JL, Beaton DB and LN Werner Soil fertility and fertilizers. An Introduction to nutrient management. $6^{\text {th }}$ edition ed. Prentice Hall New Jersey. 1999. 